\title{
Driving Economic Growth by Promoting Manufacturing in India
}

\author{
Mayank, Rachana Arya
}

\begin{abstract}
For driving economic growth at the time of COVID19 pandemic our Prime Minister has given a policy "Make in India: zero defect zero effect". The aim is to alter the country into a worldwide industrialized hub. He encourages the organizations to manufacture their goods in India. Global industries are invited to formulate investment and locate factories in India and develop their merchandizes. But the question arrived why they will setup their industries? By using India's extremely capable and skilled workforce, they generate zero defect output. What are the sectors where India can do better? Research for all the parameters are done in this paper. What are the different policies for lower and middle class people and how they will boost up their growth and help to develop the economy? Prime Mistier also focus on " $3 D$ " outlook policy: Democracy, demography and demand. Skill expansion programs are especially launched for people of rural cities.
\end{abstract}

keywords: - Make in India, Indian economy, challenges, Vocal for local

\section{INTRODUCTION}

In country like India population is increases by degrees. During this Covid-19 pandemic everybody suffers a lot either the businessmen or the consumer. Life changes as time changes but it will teach a lot. Life taught us to live it, to play with kids, to grow plants, work from home, study at home and cover up with mask and sanitizers and all. Felling like life without internet is nothing, when you want to meet other. Watsapp and team like application downloaded several time on smart phones and tablet. Online delivery of goods and products was not available so "one mantra" sounds in our hearts that is "vocal for local" on 12 May 2020 by Prime Minister Mr. Narendra Modi. Local products that cannot find their space on the global world will regenerate their hopes with these words. The purpose behind this is to sustain the goal "Aatmnirbhar Bharat". If people of India will support the local product then all over the world popularity of these goods will enhanced.

\section{THE SWADESHI MOVEMENT}

The motto is to help in intensifying the startup system by multifold. In our country population density is increasing on the metros cities only. Everybody force to do job at big cities because job opportunities, MNCs and future growth are showing a good graph about life.

Manuscript received on March 03, 2021.

Revised Manuscript received on March 11, 2021.

Manuscript published on March 30, 2021.

Mr. Mayank, Assistant Professor, Department of Biochemical Engineering, B.T.Kumaon Institute of Technology, Dwarahat, (Uttrakhand), India.

Ms. Rachana Arya, Assistant Professor, Department of Electronics and Communication Engineering, B.T.Kumaon Institute of Technology, Dwarahat, (Uttrakhand), India.

(C) The Authors. Published by Blue Eyes Intelligence Engineering and Sciences Publication (BEIESP). This is an open access article under the CC BY-NC-ND license (http://creativecommons.org/licenses/by-nc-nd/4.0/)
But the fact is government cannot produce too much jobs for every citizen. The youth is full of energy with good qualification. $\mathrm{F}$ they will start some startups then they will producing more jobs in spite of finding jobs. Some examples are Amul, Boroline, Patanjali, Dabor etc. are global fame companies. If more local brands come to existence the $\$ 5$ trillion economy is not a big dream. In this Covid-19 pandemic every people wants local item for daily needs like vegetables to flour, cloths to medicines. As by the PM Modi, if local people start buying the Indian mad products then they make them brand and feel proud about it.

\section{LIVE "VOCAL FOR LOCAL" TO SET OFF GLOBAL}

This is to be understood by the people that we are promoting the Indian brands not rejecting the globalization. We fought this crisis by the local made. We survived because Indian local market has huge capability to full fill our requirements. Next to improve our home manufacturing and industrious efficiency, we can participate among the world in addition to help the humankind.

\section{TO GENERATE JOBS}

Prerequisite is tending of invention. Or in this case, scarcity is the mother of invention. Time like this, when jobs are really hard to come, it is significant to find your feet to the new market by creating opportunities for new jobs. This may possibly setting up your dream production passing through online market. In this era all people wants organic products like vegetables, grains, free from chemical food items, herbal products for skin care, biodegradable stationeries like that. We know that factory made product cost more as well as no purity assurance. When local production is more enough to export then local business will bloom and more jobs will creates. By a small idea comes from an Indian mind can break the boundaries of trading, Tata nano, Jio, Lizzat papad are the live examples. Starting your own business and go it to online will help people in remote areas to do something better by your place.

\section{JUST DO NOT PURCHASE, PROMOTE TOO}

When a foreign living Indian wears Indian cloths for some specific brand he is already promoting that. Or Indian spices that are the thumb mark of Indians. Haldiram, MDH, Shanaaz beauty products or many other Indian brands are global brands not only because of purity but the marketing strategy. By supporting local products we are also the part of the marketing them.

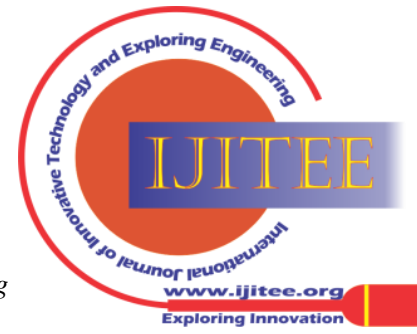




\section{Driving Economic Growth by Promoting Manufacturing in India}

Crowd has to support the local manufacturing so the supply chain management will boost the Indian economy. By encouraging the strengths of the nation, it comes to step up in this distress time.

\section{HOW TO STRENGTH THE NATION?}

It has believed that the imported tools provide us with the premium features and services. The market price is also cheaper. But we never reach the darker side of it. Those are:

- Inadequate research \& expansion

- Be deficient in familiarity over the Indian client demands

- $\quad$ Requirement is more and supply is less

- Be short of relative features which client demands for

- Poor post sale services

- Veto software are used for data processing

- Generalized goods for all weather conditions, Be deficient over unspecific climatic \& environmental circumstances of other country

\section{YOUTH TRUST AND SKILL DEVELOPMENT}

Prime Minister's priority is to enhance the skills of Indian youth so they open "pradhan mantri kaushal vikas kendra" where at a person with minimum qualification can also learn the industry specific skills. We have a huge man power and if they are skilled they can earn money easily and uplift their living standards. Not only theory based program but to acquire enough practical knowledge related to industry based, they can easily grasp the technical knowledge. The government of India is synchronizing between the skill management and job seekers. The quality education is also a part of it. Some experts say that skill and quality both cannot be intermingle. They both are different areas for different objectives. So institutions like ITI are located in different states to generate local man power as per industry needs.

Our young people will obtain employment, their family will be strengthened and their purchase power will support our economy. ," Prime Mistier Mr. Modi tells this to top industrialist.

\section{ADVANTAGES OF SKILL DEVELOPMENT}

By the skill development strategy various measures are highlighted these are:

- Develop the social attitude to the trainees, help them by vocational training, addition of skilling development as well as provides certification and diplomas courses from universities and community.

- By gratitude those of prior learning based skills can be certified to improve employability.

- By using the eminence faculties for skill training to the trainers, their money-spinning career can be growing.

- Through the help of national portal trainee can get location specific skill courses easily. Skilled based training helps them to find good opportunities for apprenticeship in industries.

- Business recognition by certified skill by the side of willingness helps to recompense premium in gratitude of better effectiveness and output.
- Get power of modern technology by using online courses, virtual classrooms and animated content, to ensure quality courses.

- $\quad$ They make certain skill courses that cover the necessary soft skills, like language, basic computer and fiscal literacy.

These types of policies are really helpful for youth over and above for those who wish to turn out to be entrepreneurs.

\section{MADE BY INDIANS, FOR THE WORLD!}

Self-reliant India meant for self sufficient country to produce and promote their business, expand their growth and economy. The culture is being developed in this pandemic to do something new, work on your ideas and design good things that will develop the growth of the country. Every human being has different nature, ideology and mind. India is a growing country and we can create a history if we will use make in India products. We require local industries to sustain. The job creation and formation is the need of growing India. By different apps anybody come their business to online market. With the help of different courier companies the product can easily reach everywhere in India as well as global market. Many website are already promoting local vendors to support them. Our government policies are even better to start your own.

\section{CONCLUSION}

In this pandemic time, humans are supposed to think again about their future. People residing in metro cities are back to their natives and thinking to do something that will help them to earn. Many operational factories needs local workers but they don't want to come back. They want to live with their families and relatives. In a diminutive break of time, the past working culture is obsolete and replace with apparent and easy to use system. It will definitely help to drive investment, encourage innovation, build up skills to the youth, shield the online transaction and make the best industrialized infrastructure. By abridgment it feels if we love and respect our country we have to think about the aim and vision of the slogan. And try to think something new innovative ideas for betterment of Indians.

\section{REFERENCES}

1. Rohit Bansal and Manisha Goyal "Make In India: Challenges And Opportunities" International Journal of Techno-Management Research, Vol. 04,Issue 02, September 2016, ISSN: 2321-3744

2. Government of India, Make In India Official website

3. Dr. M. Kabir Hassan, The impact of globalization on the developing countries, Journal of Economic Cooperation Among Islamic Countries, Vol. 19, pp.71-135 1-2,1998

4. Kamna Dhawan," Indian Entrepreneurs in Import Substitution - Need of the Hour for Indian Economy", Aisect University Journal, Vol. 02 , Issue 04, Sep. 2013. ISSN: 2278-4187.

5. R. Bhattacharyya, "The Opportunities and Challenges of FDI in Retail in India", IOSR Journal of Humanities and Social Science, Vol.5 (5), pp. 99 - 109, 2012

6. Katta Swathi," Make In India: Issues \& Challenges" Zenith International Journal of Multidisciplinary Research, Vol.8 (1), pp. 220 226, January 2018, ISSN 2231-5780 
7. Vishal Vishnoi," make in India Initiative: A Key for Sustainable Growth”, VIJOMR, Vol.05, No.02, pp. 78-85, July December 2017

\section{AUTHORS PROFILE}

Mr. Mayank is an Assistant Professor of Biochemical engineering Department, B.T.Kumaon Institute of Technology Dwarahat, Almora (Uttrakhand) . He obtain his bachelor's degree from kumaon university, Nanital in 2004 and Master's degree from Banaras hindu University, Varanasi in 2006. He is currently Ph.D. student and his research is centered on anaerobic digestion of lignocellulosic biomass to produce biofuels.

Ms. Rachana Arya has been in teaching for 14 years and currently working as Assistant Professor at ECE Department in B.T.Kumaon Institute of Technology, Almora, Uttrakhand, India. She has received the B.Tech degree in Electronics and communication from U.P. Technical University, Lucknow, M.Tech degree in Digital Communication from Uttrakhand Technical University,Dehradun, India. Currently he is doing PhD in VLSI. She has published 15 technical papers in International conferences and journal in the areas of VLSI design. Her research area of interest include, Low power VLSI, Clock Synchronization, ADPLL etc. 